Jurnal Civics: Media Kajian Kewarganegaraan
https://journal.uny.ac.id/index.php/civics/index
$1829-5789$ (print)
$2541-1918$ (online)

\title{
Peranan pusat kajian perlindungan anak dalam menjalankan hak asasi anak jalanan ditinjau dari pasal 11 Undang-Undang Nomor 23 Tahun 2002 tentang Perlindungan Anak
}

\author{
Hotma Siregar ${ }^{\text {a, }}$ * $^{*}$ \\ ${ }^{a}$ Fakultas Keguruan dan Ilmu Pendidikan, Universitas Muhammadiyah Sumatera Utara, Medan, \\ Indonesia \\ ${ }^{1}$ hotmasiregar@umsu.ac.id* \\ *korespondensi penulis
}

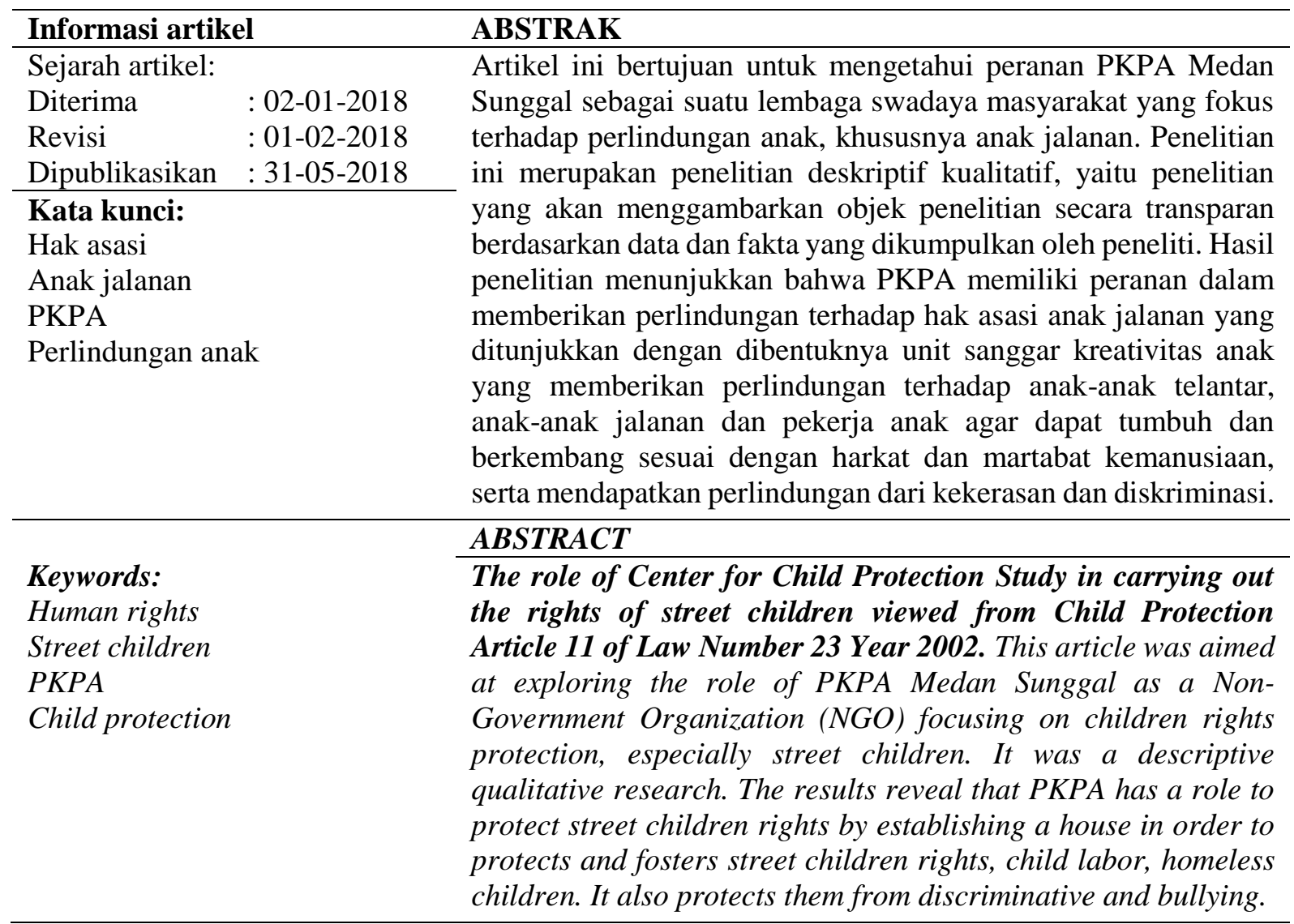

Copyright (C) 2018 Hotma Siregar

\section{Pendahuluan}

Setiap manusia memiliki hak asasi sebagai anugerah Tuhan Yang Maha Esa yang dibawanya sejak lahir. Konsekuensinya setiap manusia itu berhak mendapatkan, memiliki dan diakui hak asasi manusianya. Tidak ada seseorang pun yang dapat merampas hak asasi orang lain. Demikian juga, seorang anak memiliki hak asasi yang melekat pada dirinya sebagai anugerah Tuhan Yang Maha Esa. Bahkan anak yang masih dalam kandungan pun memiliki hak untuk hidup, sehingga perlu mendapat perlindungan dari orang-orang yang tidak bertanggung jawab terhadap usaha pengguguran kandungan.

Anak-anak merupakan tunas bangsa dan negara yang harus di pelihara dan di lindungi agar tumbuh dan berkembang dengan baik. Anak disebutkan dalam Undang-Undang Nomor 23 tahun 2002 tentang Perlindungan Anak adalah "seseorang yang belum berusia 18 (delapan belas) tahun, termasuk anak yang 
masih dalam kandungan". Lebih jauh Ansell (2005) mengatakan bahwa tidak ada definisi universal mengenai anak, menurutnya anak dalam definisi dari PBB berumur antara 0 sampai 17 tahun. Dikatakan anak adalah ketika seseorang itu belum pernah kawin, artinya tidak sedang terikat dalam perkawinan ataupun pernah kawin dan bercerai. Apabila si anak sedang terikat dalam perkawinan atau perkawinannya putus karena perceraian oleh karena itu si anak dianggap sudah dewasa walaupun umurnya belum genap 18 (delapan belas) tahun (Gosita, 2002).

Proses awal tumbuh kembang seorang anak merupakan tanggung jawab keluarga. Dalam keluarga seorang anak akan mendapatkan perawatan, pemeliharaan, kasih sayang dan kehangatan emosional dari hubungan dengan orang tua dan saudaranya. Akan tetapi, tidak semua anak tumbuh dan berkembang dengan baik dalam keluarga yang harmonis. Banyak anak-anak yang tumbuh dan berkembang di keluarga yang tidak harmonis, bahkan di jalanan tanpa perawatan dan kasih sayang dari orang tuanya. Pada hakikatnya anak tidak dapat melindungi diri sendiri terhadap berbagai macam ancaman mental, fisik, sosial dalam berbagai bidang kehidupan dan penghidupan. Oleh karena itu anak harus dibantu orang lain dalam melindungi dirinya mengingat situasi dan kondisinya. Melindungi anak adalah melindungi manusia dan membangun manusia seutuhnya. Perlindungan anak merupakan hal yang sangat penting demi terciptanya kontinuitas negara, karena anak merupakan cikal bakal suatu generasi manusia dalam pembangunan bangsa. Perlindungan anak adalah suatu usaha mengadakan kondisi dan situasi yang memungkinkan pelaksanaan hak dan kewajiban anak secara manusiawi positif (Gosita, 2002, hal. 45)

Anak jalanan atau sering disingkat anjal adalah sebuah istilah umum yang mengacu pada anak-anak yang mempunyai kegiatan ekonomi di jalanan, namun masih memiliki hubungan dengan keluarganya. Hingga kini belum ada pengertian anak jalanan yang dapat dijadikan acuan bagi semua pihak.
Perserikatan Bangsa-Bangsa

(PBB)

mendefinisikan anak jalan sebagai "boys and girls for whom 'the street' (including unoccupied dwellings, wasteland, etc.) has become their home and/or source of livelihood, and who are inadequately protected or supervised by responsible adults"(Benitez, 2011; Black, 1993; Volpi, 2002). Dengan kata lain bahwa anak jalanan adalah mereka yang menjadikan jalanan (dalam pengertian yang paling luas, termasuk pemukiman dan tanah kosong) sebagai tempat tinggal mereka yang sesungguhnya lebih dari keluarga mereka sendiri, tanpa perlindungan, pengawasan maupun pengarahan dari orang dewasa yang bertanggung jawab atas diri mereka.

Sebagian besar dari anak jalanan yang ada, adalah anak-anak dari golongan ekonomi menengah ke bawah. Akibat rendahnya pendapatan keluarga menyebabkan seorang anak harus bekerja untuk mendapatkan uang. Cara yang dianggap mudah bagi seorang anak untuk mendapatkan sejumlah uang adalah dengan turun ke jalan. Di sana anak-anak tersebut dapat melakukan pekerjaan seperti mengamen, menyemir sepatu, membersihkan angkutan umum, atau pedagang rokok. Anak jalan kategori ini tidak sepenuhnya berada di jalan dan disebut sebagai "children "of"/on" the street", berarti anak-anak yang bekerja di jalanan pada siang hari dan kembali ke rumah untuk keluarga mereka di malam hari (Benitez, 2011, hal. 6-7).

Pekerjaan apapun yang dilakukan anakanak di jalanan akan membawa risiko bagi keselamatannya. Anak yang hidup di jalanan rentan terhadap kekerasan yang dilakukan teman sebaya atau orang dewasa, bahkan kekerasan seksual. Kerasnya kehidupan jalanan akan membawa pengaruh negatif terhadap pertumbuhan dan perkembangan fisik dan psikis anak. Secara emosional anakanak tersebut akan mudah terpengaruh untuk melakukan perkelahian satu sama lain. Anakanak yang pada seusia itu yang seharusnya belajar, bersekolah dan bermain dalam pengawasan orang tuanya, malah harus berada di jalanan untuk melakukan pekerjaan. 
Stereotip anak jalanan selama ini dikategorikan sebagai korban dan juga sebagai perilaku menyimpang. Akan tetapi faktanya mereka menolak label "korban" atau "menyimpang". Mereka menghias kehidupan jalanan sehingga menjadi menyenangkan di mata mereka. Alih-alih mengeluh tentang kehidupan mereka (yang dianggap bentuknya buruk), mereka memperkuat hal-hal yang mereka rasa bagus tentang hidup di jalanan. Selama berbulan-bulan atau bertahun-tahun anak-anak jalanan dan remaja belajar untuk berinteraksi dan sesuai dengan harapan kelompok mereka sendiri, dan lebih dipengaruhi olehnya (Beazley, 2003a, 2003b).

Permasalahan anak jalanan yang menarik untuk disimak adalah mengenai eksistensi mereka yang tak terlindungi oleh perangkat hukum. Kasus pemukulan dan penangkapan anak jalanan kerapkali didengar, karena dianggap mengganggu ketertiban lalu lintas. Padahal keberadaan mereka di jalanan sekadar mencari nafkah yang menopang perekonomian keluarga. Kasus-kasus penggusuran, pelarangan, penangkapan dan pemukulan yang menimpa anak jalanan menjadi bukti bagaimana pembangunan mementingkan struktur formal yang bermodal dan mampu membayar pajak kepada Negara, sehingga public space of economy dikuasai dan dimonopoli oleh struktur formal. Potret pembangunan sangat diskriminatif dalam memperlakukan sector informal, baik karena logika ekonomi yang dianut, maupun karena legitimasi nilai formal yang melatarbelakanginya. Indonesia masih memiliki kompleksitas persoalan anak yang hingga saat ini belum terselesaikan secara menyeluruh dan komprehensif.

Walaupun batas usia anak adalah 18 tahun menurut konvensi anak, hak-hak anak atas perlindungan terhadap kekerasan, abuse dan eksploitasi tidak boleh dibatasi karena usianya. Kapasitas terbatas anak untuk melindungi diri sendiri selalu membawa makna bahwa pertimbangan-pertimbangan usia dan kapasitasnya hanya dapat memperkuat hak-hak atas perlindungan, bukan memperlemah. Misalnya, UN Rules for the Protection of Juvenile Deprived of their Liberty mengakui dalam pasal 67 , kebutuhan untuk menafsirkan hak-hak atas perlindungan dengan cara yang sesuai bagi anak ketika peraturan tersebut menentukan bahwa pemenjaraan anak secara soliter merupakan kekejaman, perlakuan atau hukuman yang tidak manusiawi dan menistakan, sementara prinsip itu tidak dengan sendirinya akan berlaku untuk orang dewasa (O'Donnell, 2013, hal. 6). Sejumlah permasalahan anak yang ada di Indonesia bukan berarti karena tidak adanya perhatian pemerintah sama sekali. Banyak hal yang sudah dilakukan pemerintah, baik itu kebijakan, upaya konkrit yang sudah diimplementasikan, berbagai regulasi dan legislasi, perencanaan dan penganggaran serta pembentukan kelembagaan yang bias mengatasi masalah anak secara sistematis.

Indonesia telah memiliki undang-undang khusus mengatur mengenai masalah anak yang berhubungan dengan hukum, yakni Undang-Undang Nomor 3 Tahun 1997 tentang Pengadilan Anak yang memberikan perhatian dan spesifikasi khusus bagi anakanak yang disangka melakukan tindak pidana. Undang-undang ini juga memberikan kekhususan, baik dalam penyidikan, penahanan, penuntutan, peradilan hingga penempatan di lembaga pemasyarakatan anak. Sebagai puncak dari upaya legislasi adalah lahirnya Undang-undang No. 23 Tahun 2002 tentang perlindungan anak. Undang-undang ini memberikan nuansa yang lebih komprehensif dalam upaya negara memberikan perlindungan pada anak di Indonesia. Dalam Pasal 11 Undang-undang tentang Perlindungan Anak dicantumkan:" Setiap anak berhak untuk beristirahat dan memanfaatkan waktu luang, bergaul dengan anak yang sebaya, bermain, berekreasi dan berkreasi sesuai dengan minat, bakat, dan tingkat kecerdasannya demi pengembangan diri." Dari bunyi ketentuan Pasal ini, terlihat bahwa seharusnya seorang anak itu berkreasi sesuai dengan minat dan bakat yang dimilikinya. Demikian juga halnya dengan anak-anak jalanan dan miskin berhak untuk bermain, mengembangkan potensi dirinya 
sesuai dengan minat, bakat dan tingkat kecerdasannya, serta bebas dari berbagai bentuk kekerasan. Namun, dalam kenyataannya anak-anak miskin kota yang berada di jalanan sulit untuk dapat mengembangkan potensi dirinya sesuai dengan bakat dan minatnya, bahkan cenderung terancam mengalami kekerasan.

Menyikapi banyaknya kekerasan terhadap anak, di Sumatera Utara dibentuk satu Lembaga Swadaya Masyarakat Pusat Kajian Perlindungan Anak (PKPA) yang didirikan pada tanggal 21 Oktober 1996 dengan status Badan Hukum Yayasan, telah mendapatkan pengesahan dari Departemen Hukum dan HAM Republik Indonesia Nomor AHU-4047.AH.01.02 Tahun 2008, serta terdaftar di Badan KESBANG-LINMAS Provinsi Sumatera Utara. PKPA mempunyai visi yaitu terwujudnya kepentingan terbaik bagi anak. Sedangkan misinya adalah advokasi kebijakan yang diperlukan untuk meningkatkan kesejahteraan dan perlindungan anak serta penegakan hak-hak anak. Kegiatan SKA dapat memenuhi hak anak sesuai dengan isi Undang- Undang No. 23 Tahun 2002 Pasal 9 ayat (1) berbunyi, "Setiap anak berhak untuk mendapatkan pendidikan dan pengajaran dalam rangka pengembangan pribadinya dan tingkat kecerdasannya sesuai dengan minat dan bakatnya". Tujuan dari program SKA pada pengembangan intelektual berbasiskan minat dan bakat anak jalanan, agar anak jalanan tertarik dan bergabung dengan SKA-PKPA serta mengikuti kegiatan-kegiatan yang diselenggarakan. Dengan adanya pengembangan minat dan bakat anak jalanan, anak-anak dapat menyalurkan bakat yang mereka miliki dan anak jalanan mulai mengurangi aktivitasnya di jalanan serta anak-anak lebih termotivasi untuk belajar.

Berdasarkan latar belakang diatas, maka peneliti merumuskan masalahnya yaitu mengenai peranan PKPA (khususnya Sanggar Kreativitas Anak) dalam menjalankan hak asasi anak jalanan ditinjau dari Pasal 11 Undang-undang Nomor 23 tahun 2002 tentang Perlindungan Anak dengan tujuan untuk mengetahui peranan PKPA itu sendiri.
Cara SKA melaksanakan program intelektual berbasiskan bakat dengan mendata anak jalanan yang memiliki minat tertentu, setelah itu anak tersebut akan diberikan pengajaran dan bimbingan sesuai dengan bakat dan minat yang mereka miliki masingmasing. SKA juga memfasilitasi minat anak tersebut agar anak-anak dapat termotivasi belajar lebih banyak untuk mengembangkan bakat dan minat mereka masing-masing. Untuk anak-anak yang unggul dan berprestasi pada minat dan bakatnya masing-masing, SKA akan menyeleksi mereka dan memperlombakan anak tersebut hingga ke luar negeri, pada kompetisi anak jalanan sedunia, yang dilaksanakan pada negara tertentu.

\section{Metode}

Artikel ini merupakan penelitian deskriptif kualitatif yang menggambarkan objek penelitian secara transparan berdasarkan data dan fakta yang dikumpulkan oleh peneliti. Objek penelitian adalah sanggar kreativitas anak yang merupakan salah satu unit dari Pusat Kajian Perlindungan Anak. Sedangkan subjek penelitian adalah peneliti sendiri.

Untuk dapat mengumpulkan data peneliti akan menggunakan instrumen dokumentasi dan wawancara. Dokumentasi diperlukan untuk mendapat data-data tentang dasar hukum pendirian PKPA, struktur organisasinya, dan program kerjanya. Wawancara dilakukan terhadap pengurus PKPA khususnya staf Sanggar Kreativitas Anak untuk mendapatkan informasi tentang bentuk kegiatan apa yang dilakukan.

Penelitian ini diawali dengan melakukan observasi di lokasi. Observasi ini dilakukan untuk melihat kondisi riil dari SKA-PKPA serta anak-anak jalanan itu sendiri. Setelah melakukan observasi, peneliti mengumpulkan data-data berdasarkan dokumen-dokumen dan foto-foto yang dimiliki LSM tersebut yang berisi tentang bentuk-bentuk kegiatan yang dilakukannya dalam melaksanakan hak asasi anak jalanan. Selanjutnya, peneliti melakukan wawancara terhadap penguruspengurus SKA-PKPA dan anak-anak jalanan 
yang ada di sanggar tersebut. Dalam penelitian ini wawancara yang dipakai adalah wawancara tidak berstruktur.

Analisis data dilakukan melalui cara pengamatan langsung ke sanggar PKPA di Pinang Baris. Data yang diperoleh dari hasil observasi akan direduksi dan hasil reduksi akan dikelompokkan dalam beberapa kategori sehingga diperoleh informasi yang bermakna. Melalui observasi peneliti akan lebih mengetahui aktivitas anak-anak tersebut di sanggar. Pengambilan keputusan dilakukan dengan menyatakan apa yang dimengerti secara utuh, tentang suatu masalah yang diteliti.

\section{Hasil dan Pembahasan}

Penelitian ini diolah dan dianalisis berdasarkan data yang diperoleh dari pengamatan langsung ke Sanggar Kreativitas Anak-PKPA di Pinang Baris dengan melakukan wawancara terhadap pengurus yang ada di SKA (Pinang Baris) maupun yang di PKPA (Tanjung Sari).

Ada beragam faktor yang menyebabkan anak-anak turun ke jalan. Kemiskinan merupakan salah satu faktor yang banyak disampaikan oleh para orang tua dan anak. Ada beberapa temuan lapangan yang menjadikan keluarga anak jalanan merasa tidak mampu memberikan hak dasar untuk tumbuh kembang anak. Alasan-alasan tersebut antara lain pertama, jumlah beban anggota keluarga lebih tinggi dibandingkan dengan pendapatan orang tua. Mayoritas orang tua anak jalanan bekerja di sektor nonformal, seperti penarik becak, pedagang kaki lima, pekerja domestik, pemulung, dengan penghasilan 20 - 30 ribu per hari sementara jumlah anggota keluarga rata-rata lebih dari 5 orang. Kedua, ketidakmampuan keluarga mengelola keuangan keluarga untuk melihat prioritas pengeluaran rumah tangga. Misalnya biaya rokok, minuman keras si ayah, voucher hand phone dan keperluan-keperluan tersier lainnya. Kebutuhan tersebut masuk kedalam daftar pengeluaran rutin yang utama mengorbankan kebutuhan biaya pendidikan anak, gizi dan kesehatan keluarga. Ketiga, urbanisasi karena kota yang padat penduduknya dan banyak keluarga bermasalah, baik masalah ekonomi, sosial dan pendidikan rendah membuat sebagian anak-anak mereka turun ke jalan.

Perihal kemiskinan menjadi penyebab anak-anak turun ke jalan ini juga senada dengan penelitian dari RCA dan UNICEF Indonesia bahwa kemiskinan menjadi salah satu penyebab anak ke jalan dan anak-anak yang hidup dalam kemiskinan memiliki aspirasi untuk menjadi lebih baik daripada orang tua mereka, terutama demi memperoleh pendapatan tunai dari pekerjaan dengan sistem upah atau gaji (2017). Kategori kemiskinan menjadi salah satu faktor "primary risk" penyebab anak turun ke jalan (Volpi, 2002)

Akan tetapi tidak hanya persoalan kemiskinan semata sebagai alasannya. Terdapat faktor sosial lain yang mempengaruhi seorang anak yang terhempas dari keluarganya lantas menjadi anak jalanan. Penganiayaan kepada anak merupakan penyebab utama anak menjadi anak jalanan. Penganiayaan itu meliputi mental dan fisik mereka. Beberapa masalah sosial yang mempengaruhi anak turun ke jalan yakni pertama, adanya pembiaran dari orang tua terhadap anak yang meninggalkan sekolah dan menikmati kehidupan jalanan. Orang tua berfikir pragmatis, ketika anak mampu mencari uang untuk memenuhi kebutuhan hidupnya maka hal tersebut dirasa sangat menguntungkan, apalagi anak bisa memberikan setoran uang kepada orang tua maka pujian pun akan diberikan. Kedua, anak-anak sejak usia dini telah diperkenalkan dengan kehidupan jalanan, kondisi tersebut berpengaruh terhadap perkembangan fisik, psikologis dan perilaku anak. Ketiga, anak tidak menemukan tempat yang menyenangkan untuk bermain, belajar dan berinteraksi sosial dengan teman-temannya. Anak-anak kecewa dengan kehidupan keluarga dan sekolah yang tidak menjawab kepentingan dan kebutuhan anak.

Anak-anak tidak mendapatkan perhatian, kasih sayang dan perlindungan dari tindakan eksploitasi serta kekerasan di dalam rumah tangga. Kemudian anak memilih jalan pintas 
lari dari rumah meski tanpa tempat tujuan yang pasti. Bagi anak-anak seperti ini hidup di jalanan memang bukan pilihannya namun di jalanan mereka menemukan kebebasan. Anak mengenal banyak hal baru dari jalanan meski mereka tidak menyadari hal baru yang mereka dapatkan di jalan akan berisiko terhadap kesehatan, keselamatan dan masa depannya. Alasan lain anak hidup dijalan diantaranya adalah karena: (1) low family income, (2) homelessness, (3) neglect and abuse, (4) school failure, dan (5) loss of parents due to armed conflicts, natural disasters, hiv/aids and other epidemics, and refugee problems (Volpi, 2002). Hal ini dapat kita lihat dari banyaknya jumlah anak jalanan yang memisahkan dirinya dari keluarga mereka. Penelantaran anak akibat perceraian orang tua dan pasca alam. Peristiwa bencana alam yang melanda Aceh dan Nias tahun 2004 dan tahun 2005 lalu masih menyisakan persoalan bagi anak-anak.

Risiko dan dampak bagi anak di jalanan sangat besar, pertama, rentan kekerasan. Anak-anak di jalanan harus bertahan hidup dengan kemampuan dan caranya sendiri karena di jalanan anak-anak menghadapi beragam konflik dan ancaman kekerasan. Tindak kekerasan dapat dilakukan oleh siapa pun. Mulai dari sesama anak jalanan, terutama anak jalanan yang lebih dewasa, sampai kekerasan antar geng anak jalanan. Pelaku lainnya adalah orang-orang dewasa di sekitar jalanan, seperti preman atau orang tua yang ingin mengambil keuntungan dari anak jalanan, dan pelaku kekerasan lainnya adalah sopir.

Bagi anak jalanan, bahkan aparatur pemerintah, khususnya satuan polisi pamong praja (Satpol PP), juga merupakan ancaman kekerasan. Karena ketika melakukan razia aparat Satpol PP sering menggunakan kekerasan. Tindakan kekerasan yang terjadi tidak hanya kekerasan fisik, namun juga kekerasan verbal yang dilakukan orang di sekitarnya. Kekerasan verbal ini berbahaya bagi perkembangan anak. Kekerasan verbal pada anak merupakan semua bentuk ucapan orang tua maupun orang di sekitarnya kepada anak yang bersifat mengancam, menakuti, dan menghina. (Fitriana, Pratiwi, \& Sutanto, 2015)

Orang tua juga kerap menjadi pelaku kekerasan anak di jalanan, karena mereka memanfaatkan posisi anak untuk mencari keuntungan ekonomi. Ekonomi, lingkungan sosial, pekerjaan, kurangnya pengetahuan mendidik anak serta pemahaman agama orang tua kurang yang turut berperan menjadi penyebab orang tua melakukan kekerasan pada anaknya. (Fitriana et al., 2015). Seringnya anak jalanan menerima perlakuan kekerasan dari banyak pihak telah menimbulkan trauma dan dendam. Anak jalanan selalu menunggu waktu dan kesempatan untuk membalaskan kekerasan yang pernah dialaminya. Akhirnya siklus kekerasan pun sulit untuk dihilangkan dari kehidupan manusia. Semua tindakan kekerasan kepada anak-anak direkam dalam bawah sadar mereka dan dibawa sampai kepada masa dewasa, dan terus sepanjang hidupnya (Huda, 2008).

Kedua, eksploitasi seksual dan trafficking anak. Kekerasan seksual terhadap anak jalanan bukanlah hal baru. Beberapa waktu lalu Indonesia dihebohkan dengan kasus "Babeh", dengan kelainan jiwa pedofilia memakan korban anak-anak jalanan di Jakarta dan Magelang yang jumlahnya mencapai 14 anak. Kejahatan kekerasan seksual pada anak, mayoritas dilakukan oleh orang yang dikenal oleh korban dan dilakukan dengan cara membujuk atau ancaman (Rohmah, Novitasari, \& H, 2007).

Fenomena kasus seperti "Babeh" memang belum pernah terungkap secara hukum di wilayah Sumatera Utara, namun bukan berarti Sumatera Utara khususnya Medan merasa bebas dari fenomena kekerasan seksual terhadap anak jalanan (Misran, 2011). Selain orang yang lebih tua yang menjadi predator bagi anak-anak di negara maju pun masalah eksploitasi seksual kerap terjadi dan disebut juga pelacuran anak. Di beberapa negara yang lebih makmur, kemiskinan tampaknya bukanlah penyebab utama pelacuran anak. Di Amerika Serikat, keluarga berantakan, kekerasan dan penelantaran, termasuk penelantaran 
emosional, merupakan penyebab utama mengapa anak meninggalkan rumah dan kemudian menjadi terlibat dalam pelacuran (O’Donnell, 2013, hal. 60).

Penjualan anak artinya "segala tindakan atau transaksi dimana seorang anak dipindah tangankan dari seseorang atau kelompok orang ke seseorang atau kelompok lainnya dengan pembayaran sejumlah uang atau karena pertimbangan-pertimbangan lainnya (UNHR, 2000). Trafficking bisa dari satu negara ke negara lainnya, namun juga dapat terjadi dalam suatu negara, sering dari daerah pedesaan ke daerah perkotaan. O'Donnel (2013, hal. 71) membedakan penyelundupan dengan penjualan, dikatakannya bahwa "penyelundupan berubah menjadi trafficking bila penipuan terhadap migran terdapat di dalamnya, atau bila mereka dipaksa tinggal dan bekerja dalam kondisi penghambaan (servitude)". Akar masalah penjualan dan trafficking sangat rumit dan saling berkaitan dan mencakup kemiskinan, kurangnya kesempatan kerja, status sosial anak perempuan yang rendah, dan umumnya kekurangan pendidikan dan kesadaran (O’Donnell, 2013, hal. 71).

Ketiga, rentan drop out. Berdasarkan data penelitian PKPA terdapat 48,2\% (107) anak jalanan yang masih berstatus sekolah. Berdasarkan karakteristik konsep anak jalanan kelompok ini disebut kelompok anak yang rentan menjadi anak jalanan. Mereka bekerja sekitar 4-11 jam per hari dan umumnya masih tinggal bersama orang tua kandung maupun orang tua pengganti. Ancaman mereka adalah pengaruh teman yang kuat yang bisa menyeret mereka lebih lama di jalan, meninggalkan rumah dan sekolah, dan memilih berkeliaran di jalan karena lebih banyak memberikan kebebasan dan kesenangan.

Daya tarik ini dirasakan semakin kuat apabila di rumah hubungan dengan orang tua kurang harmonis, orang tua yang bekerja dari pagi sampai malam sehingga anak tidak terawasi. Unsur eksploitasi dimana anak harus memberikan penghasilannya kepada orang tua, yang jika tidak maka akan menerima hukuman fisik. Karena terlalu lama berada di jalanan, anak-anak yang masih berstatus sekolah sangat rentan untuk putus sekolah.

Keempat, kecelakaan dan kriminalitas. Risiko dan ancaman terhadap anak jalanan memang sangat kompleks, selain risiko yang telah diuraikan diatas, masih terdapat risiko lain yang lebih membahayakan terhadap keselamatan, kesehatan dan masa depan anak. Beberapa situasi lain yang dapat mengancam anak jalanan adalah kecelakaan lalu lintas, jalanan tidak hanya sebagai tempat anak-anak bekerja mencari uang, namun mereka juga bermain dan melakukan beragam aktivitas dengan sesama anak jalanan; terlibat tindak kriminal, seperti mencuri, copet, judi dan tindak kriminal lainnya; dimanfaatkan oleh orang dewasa dengan mengorganisasi anak jalanan dan mengambil keuntungan secara ekonomi; dan terlibat kecanduan obat berbahaya, di komunitas anak jalanan Medan ditemukan banyak kasus anak yang mengalami kecanduan menghisap lem kaleng (jenis bahan kimia yang biasa digunakan untuk perekat ataupun barang lain). Kegiatan anak-anak ini dikenal dengan istilah "ngelem".

Anak adalah tunas, potensi, dan generasi muda penerus cita-cita perjuangan bangsa, memiliki peran strategis dan mempunyai ciri dan sifat khusus yang menjamin kelangsungan eksistensi bangsa dan negara pada masa depan. Oleh karena itu, setiap anak harus mendapatkan hak-haknya. Salah satu lembaga swadaya masyarakat yang fokus terhadap persoalan anak khususnya anak jalanan adalah Yayasan Pusat Kajian dan Perlindungan Anak (PKPA). Sejak tahun 1998 membentuk unit layanan Sanggar Kreativitas Anak (SKA) di komunitas Pinang Baris, Medan. Sanggar tersebut secara khusus mendampingi dan mengembangkan program pencegahan dan penggalian bakat-bakat yang dimiliki oleh anak jalanan. Keberadaan LSM Sanggar Kreativitas anak ini menarik untuk dikaji karena merupakan rumah singgah bagi anak-anak yang memerlukan perhatian khusus dan tidak hanya menjadi tanggungjawab pemerintah semata. Di tengah keterbatasan anggaran maupun kelemahan 
pendekatan penanganan anak jalanan yang dilakukan oleh pemerintah, keberadaan rumah singgah sangat diperlukan sebagai mitra pemerintah, dalam beberapa hal rumah singgah telah mampu memainkan peran penting dalam melakukan penanganan anak jalanan yang tidak dapat dilakukan oleh pemerintah (Suyatna, 2011, hal. 42).

Program yang dilakukan SKA-PKPA ini sesuai dengan amanat undang-undang perlindungan anak. Pengembangan kreativitas anak jalanan menjadi penting sebagaimana hasil penelitian Tjahjorini, Slamet, \& Asngari (2007) yang mengemukakan bahwa pembinaan di rumah singgah yang sebenarnya paling dipahami/disukai anak jalanan adalah pembinaan keterampilan. Oleh karena itu beberapa program pencegahan dan pengembangan bakat yang berhasil di kembangkan oleh SKA-PKPA di Pinang Baris yaitu pertama, dengan sekolah sepak bola untuk anak jalanan "SSB Scorpions".

Keinginan untuk bermain sepak bola melalui sekolah-sekolah sepak bola di Kota Medan bagi anak jalanan dan anak-anak komunitas miskin kota lain hanyalah sebuah mimpi yang sulit terwujud. Mahalnya biaya yang harus dibayar kepada pengelola sekolah sepak bola membuat anak-anak dengan potensi besar hanya tersalurkan di jalan-jalan kecil atau kompleks terminal bus di saat kendaraan sedang sepi.

Diawali dari kerja sama dengan manager Sekolah Sepak Bola (SSB) Sinar Sakti Medan, anak jalanan dari dampingan SKAPKPA diterima sebagai siswa SSB Sinar Sakti. Setelah kemampuan anak-anak bermain sepak bola mulai bagus, ada keputusan untuk mendirikan sekolah sepak bola sendiri karena dipandang lebih mudah meningkatkan pengembangan dan keikutsertaan pada even-even pertandingan. Pada tahun 2004, mulai disusun manajemen SSB Anak Jalanan SKA-PKPA yang diberi nama SSB Scorpions. Nama Scorpions diambil dari seekor hewan berbisa atas usulan dari seorang Anak Jalanan bernama Khairul Amri. Anak-anak berharap Scorpion akan menginspirasi menjadi kekuatan yang dapat mematikan lawan.

Sekolah Sepak Bola (SSB) Scorpions telah disahkan sebagai Penyelenggaraan Sekolah Sepak Bola sesuai Surat Keputusan dari Pengurus Daerah (Pengda) Persatuan Sepak Bola Seluruh Indonesia (PSSI) Kota Medan, dengan Surat Keputusan nomor: 015/SSB-PGDSU-B/XII/05 dan ditetapkan di Medan tanggal 23 Desember 2005. Sebanyak 38 anak dari 100 anak yang diseleksi menjadi tim inti SSB Scorpions. Selama berdirinya SSB Scorpions telah melakukan berbagai pertandingan baik yang bersifat persahabatan, kompetisi lokal, kompetisi resmi dari Pemerintah dan PSSI Sumatera Utara. Rekor terbaik dari SSB Scorpions adalah Juara 1 Turnamen Sepak Bola antar SSB Tingkat Provinsi Sumatera Utara. SSB Scorpions bukan sekadar penyaluran hobby bagi anakanak jalanan dan anak komunitas miskin kota, namun pembinaan SSB Scorpions menjadi wadah pengembangan bakat professional dan karier anak jalanan menuju masa depan yang lebih baik melalui bakat sepak bola. Namun mimpi itu masih sulit untuk diwujudkan karena Scorpions mengalami banyak kendala.

Kedua, bakat bernyanyi "dari Jalanan ke Studio Rekaman". Menjadi pengamen merupakan pekerjaan yang banyak dilakukan anak-anak di jalanan untuk mendapatkan uang dari pengguna jalan. Seperti yang terlihat dari data penelitian ini, anak jalanan yang menjadi pengamen mencapai $48 \%$. Anak jalanan laki-laki maupun anak jalanan perempuan menjadi pengamen merupakan pilihan utama.

Meski harus diakui bahwa tidak secara keseluruhan anak-anak yang menjadi pengamen memiliki vokal yang bagus dan kemampuan bermusik yang indah. Sebagian hanya berdiri, sambil menyuarakan “...esreg...esreg...”. dari sejumlah tutup botol yang dipaku pada sebatang kayu lantas menghasilkan rupiah. Namun tidak sedikit jumlahnya pengamen jalanan yang memiliki kemampuan bermain musik yang bagus dan menjadi selebritis di panggung nasional. Beberapa nama musisi yang cukup terkenal di panggung nasional seperti Iwan Fals, 
Almarhum Mbah Surip, Group Musik Klantink, dan seorang penyanyi muda dari ajang kompetisi Idol bernama Aris, mereka adalah musisi yang mengawali aksinya dari jalanan.

Melihat potensi dan minat yang sangat besar di bidang musik ini, banyak lembaga yang membuka akses bagi anak jalanan untuk belajar dan berkarier secara profesional dengan menyediakan fasilitas belajar musik. Hal ini yang dilakukan oleh SKA-PKPA dengan menyedia "studio musik" anak jalanan. Salah satu group musik yang lahir dari studio musik SKA-PKPA adalah Flowren Z. Meski hanya terdiri dari kumpulan anak-anak jalanan namun Flowren $Z$ telah berhasil merilis album yang diberi judul "Terbelah". Sepuluh buah lagu hasil ciptaan anak-anak ini telah dirilis atas dukungan program ROMPI Kementerian Pemuda dan Olah Raga pada tahun 2008.

Flowren $Z$ juga pernah mendapat kesempatan tur dan music show keliling Jawa dan Sumatera bersama 12 grup musik lainnya dari berbagai kota di Indonesia. Kegiatan yang dikelola oleh salah satu Production House bernama Max Production (MP) di Jakarta tahun 2009. Aksi-aksi panggung untuk penyaluran bakat musik, personil Band Flowren $Z$ juga mendapat hasil dari manggung nya di Kota Medan antara lain: Food court Amaliun, Radio Star FM, Radio Symphony FM, Merdeka Walk dan kafe-kafe ternama di Kota Medan.

Ketiga, PAUD "Pencegahan Anak Turun Ke Jalanan sejak Dini”. Sekolah non-formal PAUD (Pendidikan Anak Usia Dini) di SKAPKPA Pinang Baris resminya terbentuk pada tanggal 7 Januari 2007. Kehadiran anak-anak usia dibawah 5 tahun setiap hari di SKAPKPA melatarbelakangi pembentukan PAUD tersebut. Mereka datang bersama kakakkakaknya yang mengikuti bimbingan belajar Sekolah Dasar (SD) dan Sekolah Menengah Pertama (SMP) oleh para pendamping anak jalanan.

Selama mendampingi kegiatan bimbingan belajar pada pagi hari, selalu ada sekumpulan anak-anak usia 2-5 tahun yang datang dari sekitar tempat tinggal SKA-
PKPA. Pagi-pagi mereka datang ke SKA dengan kondisi kumal. Anak-anak kecil ini asyik bermain-main di SKA, mereka membongkar-bongkar buku yang ada di rak perpustakaan, seolah-olah mereka belajar. Terkadang jika pendamping sudah selesai memberikan pelajaran untuk anak-anak SD dan SMP, mereka memberikan pelajaran ringan kepada anak-anak yang belum sekolah ini dengan bercerita, mengenalkan huruf dan angka, mengenal bentuk, mengenal warna dan bernyanyi-nyanyi. Karena jumlahnya terus bertambah dan adanya dukungan dari orang tua untuk membentuk sekolah, maka SKAPKPA memfasilitasi berdirinya Sekolah NonFormal PAUD-SKA.

\section{Simpulan}

Perlindungan terhadap hak asasi anak merupakan tanggung jawab seluruh elemen masyarakat. Dalam kaitannya dengan ini, maka sebuah lembaga swadaya masyarakat dibentuk yaitu Pusat Kajian Perlindungan Anak (PKPA) untuk memberikan advokasi kebijakan yang diperlukan untuk meningkatkan kesejahteraan dan perlindungan anak serta menegakkan hak-hak anak. Dengan demikian PKPA memiliki peranan cukup penting dalam melindungi hak asasi anak jalanan. Hal ini sesuai dengan visi dari lembaga ini yaitu terwujudnya kepentingan terbaik bagi anak. Untuk dapat mewujudkan kepentingan terbaik bagi anak, maka Pusat Kajian Perlindungan Anak memiliki sebuah unit Sanggar Kreativitas Anak (SKA-PKPA) yang memberikan perlindungan terhadap anak-anak telantar, anak-anak jalanan dan pekerja anak agar dapat tumbuh dan berkembang sesuai dengan harkat dan martabat kemanusiaan, serta mendapatkan perlindungan dari kekerasan dan diskriminasi.

\section{Ucapan Terima Kasih}

Penelitian ini tidak mungkin bisa terlaksana tanpa bantuan banyak pihak. Untuk itu peneliti perlu mengucapkan terima kasih kepada Ketua Lembaga Penelitian dan Pengabdian Masyarakat Universitas Muhammadiyah Sumatera Utara, yang telah 
memberi kesempatan kepada peneliti untuk mengikuti dan Direktur Pusat Kajian Perlindungan Anak (PKPA) Medan yang telah memperkenankan peneliti untuk melakukan pengambilan data.

\section{Referensi}

Ansell, N. (2005). Children, youth, and development. New York: Taylor \& Francis Group.

Beazley, H. (2003a). The construction and protection of individual and collective identities by street children and youth in Indonesia. Children, Youth and Environments, 13, 105-133. https://doi.org/10.7721/chilyoutenvi.1 3.1.0105

Beazley, H. (2003b). Voices from the argins: street children's subcultures in Indonesia. Children's Geographies, 1(2), 181-200. https://doi.org/10.1080/14733280302 198

Benitez, S. T. de. (2011). State of the world's street children: research. Street Children Series 2 (Street Chi). London: The Oasis Centre.

Black, M. (1993). Street \& working children. Florence. Diambil dari http://www.unicefirc.org/publications/pdf/igs_streetchil dren.pdf

Fitriana, Y., Pratiwi, K., \& Sutanto, A. V. (2015). Faktor-faktor yang berhubungan dengan perilaku orang tua dalam melakukan kekerasan verbal terhadap anak usia pra-sekolah. Jurnal Psikologi Undip, 14(1). https://doi.org/10.14710/jpu.14.1.8193

Gosita, A. (2002). Aspek hukum perlindungan anak jalanan. Bandung: Citra Aditya Bakti.

Huda, N. (2008). Kekerasan terhadap anak dan masalah sosial yang kronis. Pena Justisia, 7(4), 14.
Misran, L. (2011). Kaji ulang situasi anak jalanan Kota Medan. Medan: Yayasan PKPA dan KindernothilfeGermany.

O'Donnell, D. (2013). Perlindungan anak: buku panduan bagi anggota Dewan Perwakilan Rakyat. Jakarta: UNICEF in collaboration with the Inter Parliamentary Union. https://doi.org/10.1017/CBO9781107 415324.004

RCA+ Team and UNICEF Indonesia. (2017). Children and their families perspectives and experiences on poverty and social protection. Jakarta.

Rohmah, N., Novitasari, K., \& H, U. D. (2007). Kekerasan seksual pada anak: telaah relasi pelaku korban dan kerentanan pada anak. Psikoislamika, Jurnal Psikologi Islam, 12, 5-10. Diambil dari http://repository.uinmalang.ac.id/880/7/kekerasanseksual.pdf

Suyatna, H. (2011). Revitalisasi model penanganan anak jalanan di rumah singgah, 15(1), 41-54.

Tjahjorini, S., Slamet, M., \& Asngari, P. S. (2007). Persepsi anak jalanan terhadap bimbingan sosial rumah singga di Kotamadya Bandung. Jurnal Penyuluhan, 3(1), 18-23. https://doi.org/1858-2664

UNHR. Optional Protocol to the Convention on the Rights of the Child (2000).

Volpi, E. (2002). Street children: promising practices and Approaches. Washington DC: The International Bank for Recognition and Development / The World Bank. 